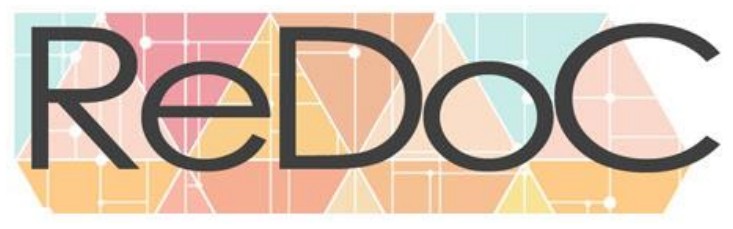

Revista Docência e Cibercultura

\title{
PENSANDO COM IMAGENS NA/DA DIFERENÇA PARA UMA SOCIEDADE DO COMPARTILHAMENTO
}

\section{THINKING WITH IMAGES IN THE / DIFFERENCE FOR A SHARING SOCIETY \\ PENSANDO CON IMÁGENES EN LA DIFERENCIA PARA UNA SOCIEDAD DEL COMPARTIR}

Resumo: Partindo das premissas dos estudos nos/dos/com os cotidianos, esta pesquisa teve como objetivo pensar com imagens compartilhadas por estudantes do terceiro ano do Ensino Médio, do Colégio Estadual Abdias Nascimento, em Nova Iguaçu, Baixada Fluminense/RJ, as noções de diferença tecidas com essa prática em suas articulações com as narrativas que engendraram. As imagens em questão foram compartilhadas na rede social da internet Facebook, em páginas correspondentes a grupos criados para este fim, denominados \#Diferença e que operaram como dispositivo de pesquisa-intervenção, situando-se em um contex to que enunciamos como "sociedade do compartilhamento". Buscamos pensar com fragmentos das redes de significações tecidas no momento em que eram compostas, problematizando conceitos, representações, dogmas e rupturas em relação a perspectivas tradicionais e hegemônicas da noção de diferença. As imagens, acompanhadas de suas narrativas/análises, nos deram pistas para pensar nos múltiplos atravessamentos e bricolagens entre imagens e ideias de diferença que são criadas e circulam nas múltiplas redes educativas e que engendram os processos curriculares nos cotidianos das escolas.

Palavras chave: Imagens, diferença, Facebook

Submetido em: 21/03/2018 - Aceito em: 21/04/2018 - Publicado em: 30/06/2018.

1 Doutor e Mestre em Educação pelo PROPED/UERJ conceito CAPES 7. Possui Graduação em Administração de Empresas pela UFF e Licenciatura pela UCAM, Especialização em Gestão Pública da Educação pela UFJF e Docência do Ensino Superior pela UCAM, Professor Docente I e Coordenador Pedagógico na SEEDUC do Governo do Estado do Rio de Janeiro. Tem experiência na área de Educação e Gestão Escolar, com ênfase em projetos, atuando principalmente nos seguintes temas: Diferença, Lei 10639/03, Racismo, Audiovisualidades, Midia, Redes Sociais e Imagens 


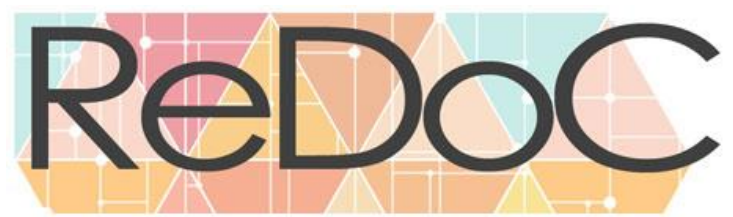

\title{
Revista Docência e Cibercultura
}

\begin{abstract}
Based on the assumptions of the studies in the day-to-day, this research aimed to think with images shared by students of the third year of High School, Abdias Nascimento State College, in Nova Iguaçu, Baixada Fluminense / RJ, the notions of difference Woven with this practice in their articulations with the narratives they engendered. The images in question were shared in the social network of the Internet Facebook, in pages corresponding to groups created for this purpose, denominated \# Difference and that operated like device of research-intervention, situating in a context that we pronounce like "society of the sharing". We sought to think with fragments of the networks of meanings woven in the moment they were composed, problematizing concepts, representations, dogmas and ruptures in relation to traditional and hegemonic perspectives of the notion of difference. The images, along with their narratives / analyzes, gave us clues to think about the multiple crossings and bricolages between images and ideas of difference that are created and circulated in the multiple educational networks and that engender the curricular processes in the daily life of the schools.
\end{abstract}

Keywords: Images, difference, Facebook

Resumen: A partir de las premisas de los estudios en los / de los / los cotidianos, esta investigación tuvo como objetivo pensar con imágenes compartidas por estudiantes del tercer año de la Enseñanza Media, del Colegio Estadual Abdias Nascimento, en Nova Iguaçu, Baixada Fluminense / RJ, las nociones de diferencia Con esta práctica en sus articulaciones con las narraciones que engendraron. Las imágenes en cuestión fueron compartidas en la red social de internet Facebook, en páginas correspondientes a grupos creados para este fin, denominados \# Diferencia y que operaron como dispositivo de investigación-intervención, situándose en un contexto que enunciamos como "sociedad del compartir". Buscamos pensar con fragmentos de las redes de significaciones tejidas en el momento en que estaban compuestas, problematizando conceptos, representaciones, dogmas y rupturas en relación a perspectivas tradicionales y hegemónicas de la noción de diferencia. Las imágenes, acompañadas de sus narrativas / análisis, nos dieron pistas para pensar en los múltiples atravesamientos y bricolajes entre imágenes e ideas de diferencia que se crean y circulan en las múltiples redes educativas y que engendran los procesos curriculares en los cotidianos de las escuelas.

Palabras clave: Imágenes, diferencia, Facebook

IMAGINANDO E CRIANDO UMA PUBLICAÇÃO: APONTAMENTOS INICIAS DE PESQUISA

"Toda imagem é uma forma que pensa"

Etienne Samain 
Clicar, postar, compartilhar, curtir e comentar vídeos, imagens e textos nas redes sociais da internet faz parte do nosso cotidiano.

Para além da internet, milhares de imagens são produzidas e circulam todos os dias nos vários meios de comunicação, seja na televisão, no cinema, nos espaços públicos e privados, em nossa casa, na nossa vida... Imagens estão, o tempo todo, à nossa volta, e constituem um dos mais importantes modos pelos quais vemos, aprendemos, pensamos, narramos e tecemos o presente.

Neste contexto imagético que compartilhamos na tessitura do nosso dia a dia com a potência da produção de imagens e publicação, quase que instantânea, nas redes sociais da internet, foi o cenário para uma pesquisa que buscou pensar e tensionar um dos modos pelos quais se realiza, a cada dia com mais frequência e intensidade, a apropriação de imagens e seus diferentes usos na produção de si e dos outros, nas redes que urdimos cotidianamente.

O texto que aqui apresentamos para o dossiê "Imagens, Narrativas e Currículo" se ocupa de alguns fragmentos da minha pesquisa de doutorado, realizada entre $2014 \mathrm{e}$ 2016, em uma escola pública de Ensino Fundamental e Médio situada na região metropolitana do Rio de Janeiro, na Baixada Fluminense, no município de Nova Iguaçu, o Colégio Estadual Abdias Nascimento, com objetivo de problematizar as ideias de diferença criadas pelos estudantes com os usos que fizeram de imagens criadas e apropriadas dentrofora da instituição de ensino. Tomando como fio condutor para os debates, uma curadoria realizada pelos estudantes, que consistiu na seleção, organização, captura e compartilhamento no Facebook $^{2}$ de imagens por eles consideradas como imagens da diferença, produzimos rodas de conversas online e presenciais que possibilitaram o questionamento e o alargamento das redes de significações e subjetividades tecidas com essas as imagens.

\footnotetext{
${ }^{2}$ Facebook é uma rede social na internet lançada 2004, considerada atualmente como a maior rede social em todo o mundo, reunindo mais de um bilhão de usuários ativos. No Facebook é possível compartilhar e comentar textos, fotos e vídeos.
} 


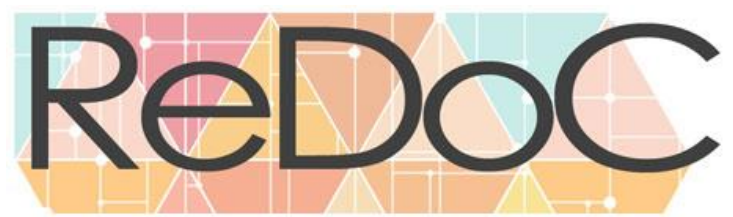

\section{Revista Docência e Cibercultura}

Assim, buscamos pensar fragmentos nas redes de significações engendradas no momento em que são tecidas para problematizar conceitos, representações, dogmas e rupturas em relação às concepções hegemônicas da diferença, forjadas com diversos modos de praticar/usar imagens em suas articulações, com diferentes discursos que circulam na sociedade, tais como produção, recepção, compartilhamento, comentários, apropriações e ressignificações.

\section{"POSTANDO": UM COTIDIANO TECIDO PELAS/COM AS IMAGENS}

Os regimes de verdade que produzimos sobre nós mesmos, os outros e o mundo estão cada vez mais associados aos usos de imagens, assim como também estão associados a esses usos, os processos de subjetivação, as disputas em torno do reconhecimento e a participação política na sociedade contemporânea.

Para Médola, Araujo e Bruno (2007, p. 3), a “cultura contemporânea é, em muitos aspectos, uma cultura da imagem". Elas estão presentes em todos os contextos do nosso dia a dia, fazem parte da nossa vida, do modo como a percebemos e dos sentidos que atribuímos a ela.

Para estas mesmas autoras, na apresentação da obra Imagem, Visibilidade $e$ Cultura Midiática, livro da COMPÓS ${ }^{3}$ 2006/2007, com as imagens, nossa vida não é algo novo:

A afirmação de que vivemos entre imagens não é recente, podemos remontá-la às origens da cultura ocidental, e esta condição, há muito, tem sido objeto de crítica e reflexão - de Platão a Debord. Há, contudo, um certo paroxismo da imagem em nossa cultura midiática, não apenas por ela mediar boa parte dos processos socioculturais - da política ao entretenimento, da ciência à arte, da sociabilidade ao consumo, entre outros - mas também e principalmente por não ser mais tão certo que no fundo, atrás, aquém ou além da imagem há o mundo, o referente, a coisa. No fundo de uma imagem há sempre outra imagem, recolocando

\footnotetext{
${ }^{3}$ XV Encontro Anual da Associação Nacional de Programas de Pós-Graduação em Comunicação, 0609/06/2006, UNESP - Universidade Estadual Paulista, Bauru, São Paulo
}

\begin{tabular}{l|l|l|l|l|l|l|} 
(C) Redoc & Rio de Janeiro & v.2 & n.2 & p. 139 & Maio/Agosto. 2018 & ISSN 2594-9004 \\
\hline
\end{tabular}




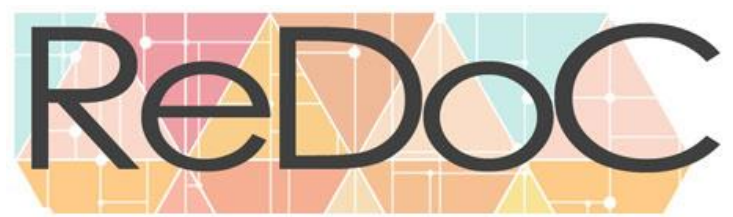

Revista Docência e Cibercultura

em xeque, e em diversos domínios da cultura, as oposições entre aparência e essência, imagem e referente. (COMPÓS, 2006/2007, p. 1314).

Vivenciamos um cotidiano constituído pelas/com as imagens. Desta maneira, nos questionamos: Como (não) pensar com imagens em nossa sociedade? Como (não) compreender que elas estão e fazem parte do nosso cotidiano? Como (não) discuti-las? Como (não) usá-las? Como (não) amá-las? Como (não) produzir conhecimentos e significações com elas?

Às vezes, ouvimos indagações sobre o uso de imagens em detrimento da escrita, de forma crítica, embora não percebamos isso de forma contundente. Percebemos que tanto as imagens quanto a escrita possuem sua importância e o seu papel nos processos de significação, pois são duas formas de pensar que se atravessam mutuamente, se enfrentam e/ou compõem uma com a outra.

Mas, no passado, as imagens que foram muito utilizadas ao longo dos séculos já foram criticadas e proibidas no que foi chamado de Iconoclasmo4. Para Arlindo Machado (2001), as críticas ao uso de imagens na sociedade "pós-moderna" situam-se no que ele denomina "O Quarto Iconoclasmo" e aponta:

[...] Em termos bastante resumidos, os novos iconoclastas apregoam que as imagens, a partir de meados do século XX, começaram a se multiplicar em progressão geométrica: elas estão presentes em todos os lugares, invadem nossa vida cotidiana, inclusive a mais íntima, influenciam nossa práxis com sua pregnância ideológica, subtraem a civilização da escrita, erradicam o gosto pela leitura e anunciam um novo analfabetismo e a morte da palavra. (MACHADO,2001, p. 16).

Não nos vemos em um mundo onde as imagens não poderiam ser utilizadas na produção de conhecimento; no qual só as palavras tivessem valor, como em tempos passados com as proibições ou as deslegitimações que as imagens sofreram. As imagens

\footnotetext{
${ }^{4}$ Iconoclasmo é uma doutrina de pensamento oposta ao culto a ícones e símbolos religiosos e políticos; toda pessoa que não venera imagem é um iconoclasta. Fonte: http://www.2014.gepsexualidades.com.br/resources/anais/4/1404610017 ARQUIVO ASNARRATIVASAUDIOVI SUAISCOMOPOTENCIALIZADORASDASDISCUSSOESSOBREGENEROESEXUALIDADE.pdf $>$.Acesso em: 07 jul. 2017.
} 


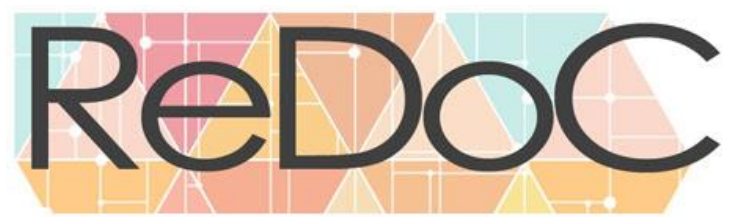

\title{
Revista Docência e Cibercultura
}

fazem-nos sentir e pensar a vida e o mundo em si. Seu uso cresce nos processos educativos e comunicacionais a cada dia, mas não podemos radicalizar e afirmar que as mesmas promovem a "morte" das palavras.

Flusser (2011), autor de Filosofia da Caixa Preta e outros livros sobre imagem, nos aponta que as imagens são utilizadas para representar o mundo e também para nos orientar nele. As imagens tradicionais (pintura, escultura) e as imagens técnicas (fotografia, vídeo) têm algo em comum e cada uma tem seu impacto, que pode mudar conforme o tempo. Assim, para este autor, "o significado das imagens é o contexto mágico das relações reversíveis" (p. 23). Ele aponta que o universo imagético produz desafios a serem enfrentados pelos seus praticantes:

\begin{abstract}
Imagens são mediações entre o homem e o mundo. O homem "existe", isto é, o mundo não lhe é acessível imediatamente. Imagens têm o propósito de lhe representar o mundo. Mas, ao fazê-lo, entrepõem-se entre mundo e homem. Seu propósito é serem mapas do mundo, mas passam a ser biombos. $\mathrm{O}$ homem ao invés de se servir das imagens em função do mundo, passa a viver em função de imagens. Não mais decifra as cenas da imagem como significados do mundo, mas o próprio mundo vai sendo vivenciado em conjunto de cenas. (FLUSSER, 2011, p. 23).
\end{abstract}

Entendemos, com Flusser (2011), que a imagem, principalmente a imagem técnica, é um artefato que produz e se articula, de alguma forma, com conceitos, às vezes hegemônicos, cuja produção está em parte inscrita na programação do aparelho e no universo fotográfico, resultando em imagens-clichê que circulam dogmaticamente na nossa sociedade, mas também, em determinadas circunstâncias, engendrando vidências outras que nos permitem vislumbrar novas possibilidades de percepção e pensamento (DELEUZE, 2000).

As imagens, como forma de pensamento, criam conhecimentos, mas, ao mesmo tempo, trazem também um conhecimento já produzido nelas sem necessariamente estarem atreladas à linguagem escrita. 


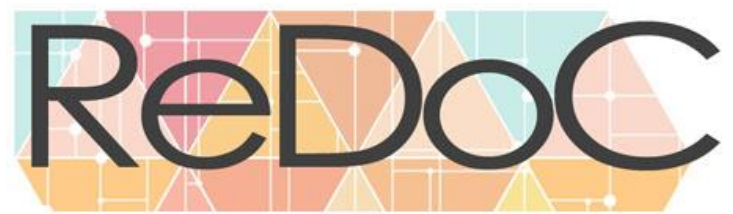

\section{Revista Docência e Cibercultura}

Não podemos deixar de observar que toda imagem pode afetar-nos, produzir problematizações, fazer pensar sobre um determinado assunto, fraturar padrões cognitivos habituais, tecer novas ideias. Entretanto, cada praticante da cultura, inclusive da cultura visual, produz as suas próprias interpretações (ou seja, atribui sentidos) acerca de uma mesma imagem, pois, como diz Nilda Alves5 em suas aulas, vemos uma imagem com as nossas redes de saberes, fazeres e afetos. É nessa perspectiva que Alves (2016) pensa as imagens como "personagens conceituais", e/ou operam como intercessores do pensamento e sem os quais é impossível pensar.

Ressaltamos que as imagens, estando implicadas nos processos de subjetivação e da tessitura das nossas redes de conhecimentos e significações, constituem vetores importantes nos processos de aprendizagem como invenção de si e dos mundos (KASTRUP, 2007).

As imagens fazem parte dos cotidianos das escolas e, dessa forma, são atuantes nas redes lá tecidas, inclusive, nas redes de conhecimentos e significações sobre a diferença e sobre "os diferentes" que lá se engendram.

\section{“CLICANDO": UMA PESQUISA COM IMAGENS NO SEIO DA CULTURA DIGITAL EM REDE}

A educação atual, mediada pelo uso das tecnologias nas práticas educacionais, que se entendem como "artefatos tecnoculturais" (SOARES \& SANTOS, 2012) e pelas diferenças que se engendram nas mais diversas redes que convergem nos ambientes escolares, nos apresentam múltiplas faces e abre para o pesquisador, enquanto forma, e se formam novas abordagens para criar e recriar suas próprias práticas.

\footnotetext{
${ }^{5}$ Professora Dr. ${ }^{a}$ do Programa de Pós Graduação em Educação da UERJ (PROPED/UERJ), autora de inúmeros livros sobre as pesquisas nos/dos/com os cotidianos.
} 


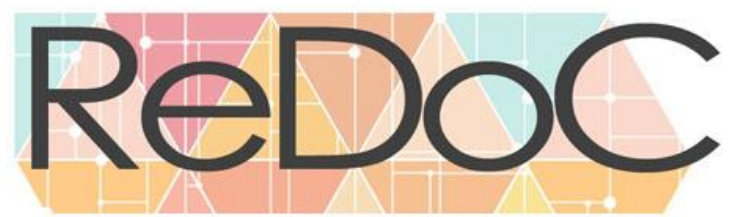

\section{Revista Docência e Cibercultura}

Os espaçostempos das redes sociais e digitais na internet se configuram no que vem sendo chamado de cibercultura. No diálogo com (SANTOS, 2014), "a cibercultura é a cultura contemporânea estruturada pelo uso das tecnologias digitais nas esferas do ciberespaço e das cidades” (p. 20). E assim:

O ciberespaço é um conjunto plural de espaços mediados por interfaces digitais, que simulam contextos do mundo físico das cidades, suas instituições, práticas individuais e coletivas já vivenciadas pelos seres humanos ao longo de sua história. Além disso, e sobretudo, instituiu e vem instituindo contextos e práticas originais e inovadoras. (SANTOS, 2014, p. 26).

Crianças e jovens fazem uso de múltiplos "artefatos tecnoculturais" como celulares e câmeras; produzem vídeos e fotografias e interagem através desses dispositivos nas redes sociais. Existe assim uma cultura da imagem difundida e vigiada pelas/nas redes sociais da internet, estabelecida por meio de compartilhamento em sites como Facebook, Instagram e Youtube, articulando processos de usos, prazer e vigilância (BRUNO, 2013).

Nesse contexto, Edméa Santos (2014) nos ajuda também a repensar a ideia de rede:

Rede aqui é entendida como todo fluxo e feixe de relações entre seres humanos, objetos técnicos e as interfaces digitais. Nessa híbrida relação, todo e qualquer signo pode ser produzido e socializado no e pelo ciberespaço, compondo assim o processo de comunicação em rede próprio do conceito de ambiente virtual de aprendizagem [...] (SANTOS, 2014, p. 60).

E ainda:

A noção de rede é a marca do social em nosso tempo. Rede significa que estamos engendrados por uma composição comunicativa, sociotécnica, que se atualiza a cada relação e conexão que estabelecemos em qualquer ponto dessa grande rede. Tempo e espaço 


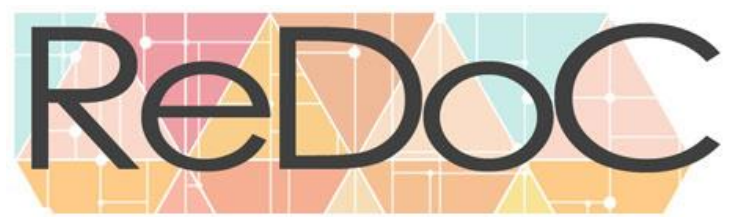

\title{
Revista Docência e Cibercultura
}

ganham novos arranjos influenciando novas e diferentes sociabilidades. (SANTOS, 2014, p. 60).

As redes sociais da internet alargam os espaçostempos de aprendizagem e trazem novas maneiras de tecer conhecimentos nos cotidianos.

Nesse sentido, ainda no diálogo com Santos (2014), buscamos uma aproximação e o entendimento de redes educativas:

\begin{abstract}
Redes educativas são espaços plurais de aprendizagem. Além dos espaços e lugares plurais, entendemos redes educativas também como modos de pensamento, uma vez que a construção do conhecimento é tecida em rede, a partir das aprendizagens construídas pela apropriação dos diversos artefatos culturais, tecnologias, interações sociais, entre outros. Aprendemos porque nos comunicamos, fazemos cultura e produzimos sentidos e significados. Enfim, significamos, com nossas redes intrapsicológicas, em interação constante por nossas múltiplas redes interpsicológicas, condicionadas pela cultura em suas multifacetadas relações. (SANTOS, 2014, p. 31).
\end{abstract}

Para pensar a relação escola-tecnologia-imagem-diferença nas redes que se cruzam e entrecruzam (ALVES, 2008), mergulhamos nos cotidianos de uma escola pública do Estado do Rio de Janeiro, O CE Abdias Nascimento, em Nova Iguaçu, Baixada Fluminense, RJ, como já dissemos, com a turma do terceiro ano do Ensino Médio, 3001/2014, baseados na metodologia das pesquisas nos/com os cotidianos. Assim, buscamos problematizar os modos pelos quais as imagens da diferença são produzidas dentrofora da escola, especialmente, os modos relacionados ao consumo, à produção, ao compartilhamento e à apropriação de imagens.

Paralelamente, os alunos da turma que foi escolhida para a pesquisa foram convidados a postar uma imagem que, para eles, significasse a "diferença”, em grupos na rede social da internet, o Facebook6, criados para este fim. Com essa finalidade, foi criada

\footnotetext{
${ }^{6}$ A história de criação do Facebook é atualmente bastante conhecida, para o que em muito contribuiu a sua abordagem no cinema em 2010com o filme A rede Social (The social network) de David Fincher, onde se conta o essencial da história verídica da criação desta rede social inicialmente designada Thefacebook. Criado em 2004 por um grupo de jovens universitários de Harvard (Mark Zuckerberg, Dustin Moskovitz, Eduardo Saverin e Chris Hughes), visava criar um espaço no qual as pessoas se encontrassem, compartilhassem opiniões e fotografias visando, no início criar uma
} 


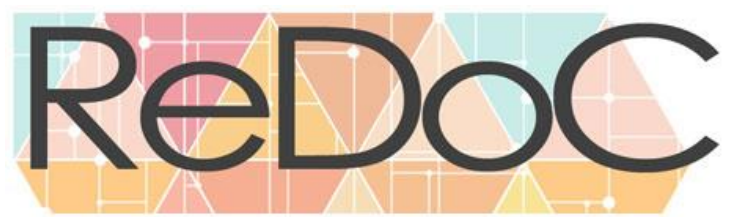

\title{
Revista Docência e Cibercultura
}

uma página para cada grupo nessa rede social que operou como dispositivo para a pesquisa que denominamos \#DIFERENÇA.

Apoiamo-nos em Foucault (2012b) para usar o termo "dispositivo" como uma função metodológica na nossa pesquisa.

\begin{abstract}
Por esse termo tento demarcar, em primeiro lugar, um conjunto decididamente heterogêneo que engloba discursos, instituições, organizações arquitetônicas, decisões regulamentares, leis, medidas administrativas, enunciados científicos, proposições filosóficas, morais, filantrópicas. Em suma, o dito e o não dito são elementos do dispositivo. O dispositivo é a rede que se pode estabelecer entre esses elementos. (FOUCAULT, 2012b, p. 364).
\end{abstract}

O autor destaca, em segundo lugar, sobre esses elementos heterogêneos: "em suma, entre estes elementos, discursivos ou não, existe um tipo de jogo, ou seja, mudanças de posição, modificações de funções, que também podem ser muito diferentes." (FOUCAULT, 2012b, p. 364).

E ainda aponta que o dispositivo tem uma função estratégica dominante como um tipo de formação e, em um dado momento histórico, como função para responder a uma urgência. E, assim, produzir "um efeito que não estava de modo algum previsto de antemão, que nada tinha a ver com a astúcia estratégica produzida por uma figura meta ou trans-histórica que o teria percebido e desejado." (FOUCAULT,2012b, p. 365).

As redes sociais na contemporaneidade ocupam um espaço privilegiado na vida, principalmente, dos jovens e estudantes.

rede de comunicação apenas para os estudantes da própria Universidade. Todavia, em poucos meses a rede expandiuse entre as universidades americanas, conectando jovens de mais de 800 instituições (ARRINGTON, 2005). A sua popularidade cresceu e em menos de um ano já tinha 1 milhão de utilizadores ativos. Em 2005 ultrapassa as fronteiras americanas e no início de 2006, algumas empresas e estudantes do ensino não superior passam a ter acesso a esta rede. Em setembro desse mesmo ano, o Facebook foi aberto a quem se quisesse registrar, mantendo apenas a restrição (teórica) da idade mínima de treze anos. No final de 2011, a rede social de Zuckerberg ultrapassou o Orkut, até então a maior rede do social do Brasil. Em dezembro de 2012 a rede social ultrapassou 1.060 milhões de utilizadores mensais ativos, sendo 680 milhões utilizadores que usam acesso móvel. Por dia, o número de utilizadores médios ativo, ronda os 618 milhos. Trata-se pois de um fenômeno único que se configura como a maior rede social do mundo (FACEBOOK, 2012 apud AMANTE, 2014, p. 29). 


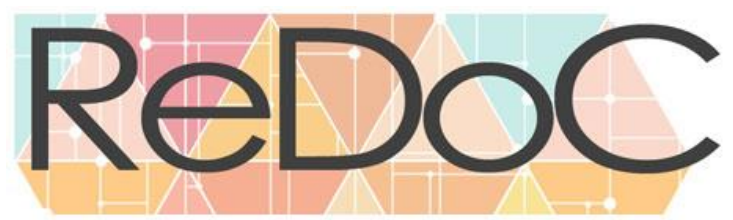

Revista Docência e Cibercultura

Assim, compreender a vida social na contemporaneidade requer considerar o estudo das redes sociais online já que estas alteram profundamente nos últimos anos a forma como milhões de pessoas se comunicam e compartilham informação entre si. Neste âmbito sendo o facebook a rede mais popular (KREUTZ, 2009) e mais disseminada, impõe-se como uma fonte privilegiada de informação aos estudiosos desta área. (AMANTE, 2014, p.28).

Com mais de um bilhão e meio de usuários em todo mundo e mais de oitenta e nove milhões de usuários em todo Brasil7, percebemos que a utilização dessa rede social como dispositivo de pesquisa nos facilitaria o acesso e uma aproximação maior com os estudantes da pesquisa.

A sociedade em rede surge como uma sociedade hipersocial, onde as tecnologias se integram no quotidiano ligando o mundo real ou virtual de tal modo que essa distinção, especialmente nos mais jovens e adolescentes a rede social é a continuação da sua vida off-line. Um e outro mundo são a mesma coisa, coexistem e fundem-se, sem qualquer distinção. (AMANTE, 2014, p. 40. Grifo do autor).

E ainda:

As redes sociais, designadamente o facebook, têm vindo a constituir-se como um espaço alternativo, onde se fazem e reforçam amizades e que, como espaço social que são, dão igualmente lugar a processos de construção de identidade de jovens. Atualmente, estar nas redes sociais constitui uma forma de gerir a própria identidade dos jovens. Atualmente, estar nas redes sociais constitui uma forma de gerir a própria identidade, estilo de vida e relações sociais. Quando um jovem faz comentários positivos sobre os seus amigos, está a favorecer a possibilidade de também os seus amigos, fazerem comentários positivos sobre si próprio. (AMANTE, 2014, p. 35).

\footnotetext{
${ }^{7}$ Fonte: <http://www.meioemensagem.com.br/home/midia/noticias/2014/08/22/Facebook-tem-89-milhoes-deusuarios-no-Brasil.html>. Acesso em: 11 jan. 2017.
} 


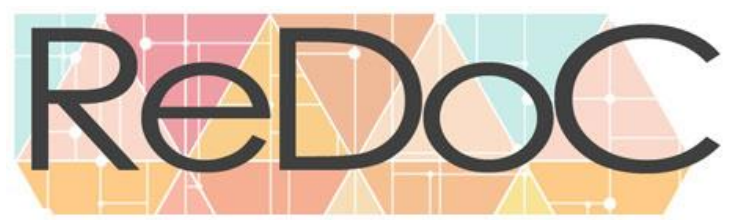

Revista Docência e Cibercultura

Como era de se esperar, todos os estudantes da turma pesquisada possuíam um perfil no Facebook e, dessa forma, poderiam compartilhar imagens e publicar seus comentários.

\begin{abstract}
Ao criar um perfil no Facebook são disponibilizados campos para diferentes informações. O quadro informação básica inclui informação sobre gênero, data de nascimento, idiomas, ideologia política e crença religiosa. O campo/formação permite inserir a pertença institucional a nível profissional e a(s) instituição(es) de formação acadêmica. É ainda possível referir o status de relacionamento, a naturalidade e a residência atual. O campo "Sobre ti" deixado em aberto, permite ao utilizador realizar uma auto-descrição. A este junta-se o campo citações preferidas e o campo relativo a contatos onde pode ser indicado apenas o endereço de e-mail, ou muitos outros dados. Há, pois, um conjunto de referências pessoais que podem ser inscritas nestes campos, permitindo traçar um perfil do utilizador mais ou menos detalhado, consoante a opção tomada por este já que estes campos não são de preenchimento obrigatório. (AMANTE, 2014 p. 30).
\end{abstract}

Dessa maneira, pensamos que a interação com os estudantes seria mais fácil, prática e até econômica. Todos poderiam postar imagens sem ter que imprimir e levar para sala de aula; poderiam fazer isso a qualquer hora, de qualquer lugar, seja na escola, em casa ou na rua, como também, poderiam escrever, compartilhando sua ideia de maneira menos formal.

Não determinamos se as imagens deveriam ser criadas por eles ou se poderiam usar imagens disponíveis em bancos de dados disponíveis em sites de busca como o "Google"; deixamos que cada um fizesse sua escolha.

Nessa contingência, mergulhar com todos os sentidos nos cotidianos das redes tecidas dentrofora da escola é também imergir nas redes sociais, nas quais professores e alunos se relacionam, interagem e criam conhecimentos e significações. 


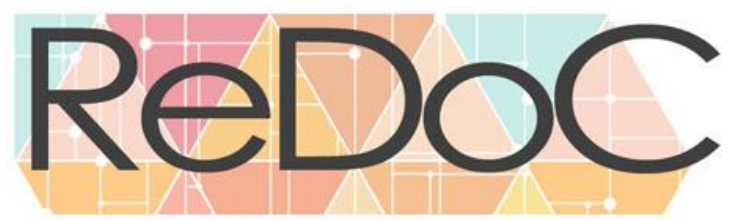

\section{Revista Docência e Cibercultura}

Sendo o Facebook, por excelência um espaço de interação e comunicação, o professor pode aproveitar as muitas horas que os seus estudantes passam conectados, para utilizá-lo como um espaço de partilha de conteúdos multimídia, de vídeos, de músicas, de fragmento de filmes ou de peças de teatro, relacionados com os temas lecionados. Para, além disso, pode, também aproveitar esse tempo para promover discussão e debates sobre os assuntos tratados (MOREIRA \& JANUÁRIO, 2014, p. 79).

Em nossa proposta, imersos numa cultura imagética e digital, solicitamos que cada estudante, em separado, deveria postar uma imagem que, para ele, significasse ou traduzisse uma ideia de "diferença" e, nesse sentido, também postar seu comentário, dizendo por que aquela imagem representa a "diferença". Ou seja, porque ele escolheu aquela imagem.

Após postar a sua imagem dentro do grupo e somente para os componentes dele, cada estudante também deveria comentar a imagem do colega do grupo. De acordo com o quantitativo de estudantes por grupo, vários comentários foram postados sobre uma mesma imagem.

Efetivamente, podemos afirmar que as redes sociais, nomeadamente o Facebook, permitem, atualmente, equacionar o processo pedagógico de forma diferente. No entanto, a mudança não deve ser vista só do ponto de vista tecnológico, mas, sobretudo em termos de mentalidade e de prática. Esta realidade implica uma alteração cultural, pois obriga a repensar os papeis dos professores e dos estudantes, e a relação existente entre eles, para além das implicações a nível da planificação de cursos e currículos, sistemas de avaliação, formas de ensinar e aprender, metas a atingir. Na verdade, o papel do professor está em mudança e aproxima-se, com o apoio digital, ainda mais, dum emoderador, ou seja, de um orientador de aprendizagens. (MOREIRA \& JANUÁRIO, 2014, p. 81).

Entendemos que as redes sociais da internet estão presentes no nosso cotidiano seja por visibilidade e vigilância, como também para entretenimento e prazer (BRUNO, 2013). 


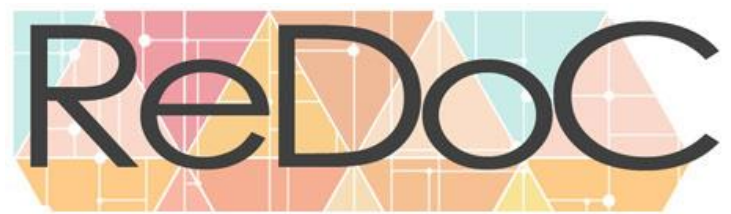

Revista Docência e Cibercultura

Assim como celulares e suas câmeras são considerados "artefatos pedagógicos" (SOARES \& SANTOS, 2012), as redes sociais da internet também têm exercido esse papel de diálogo com o fazer pedagógico de alunos e alunas no cotidiano escolar.

O conhecimento que circula em rede é para as pessoas que acessam inicialmente informações. Portanto, para transformarmos informações em conhecimentos, é preciso saber selecionar o que é pertinente para cada praticante cultural em seu contexto sócio-cognitivo e políticocultural. Não podemos ignorar que vivemos num mundo globalizado, mas com diferenças, desigualdades e singularidades (SANTOS, 2014, p. 48).

\section{“CURTINDO”: JUVENTUDES E CULTURAS AUDIOVISUAIS}

As transformações sociais dos últimos tempos reverberam na nossa contemporaneidade na qual as juventudes ocupam cada vez mais espaço e presença, criando, com isso, suas estéticas de existência e despertando interesses dos meios de comunicação, da indústria da moda, das políticas públicas.

Assistimos agora a um interesse muito grande pelas juventudes. Ou melhor, pela juventude, ainda no singular. Porque, de um modo geral, assim são vistas, como uma faixa etária determinada, uma "fase da vida". Ou seja, indivíduos com práticas, subjetividades e corporeidades idênticas, em transição da infância à vida adulta. Farto material jornalístico, com pretensa objetividade informacional e científica, é apresentado, através de diversas mídias, para explicar os jovens na especificidade de suas vidas. Vidas que parecem preocupar governos e instituições. O Estado, a família e a escola estão entre as instituições mais interessadas, preocupadas com o governo das práticas e das imagens que fazem parte das identidades juvenis. É preciso, então, dizer quem são os jovens. Descobrir suas aparências e revelar quem são realmente, essencialmente, sinteticamente. (BERINO, VICTÓRIO FILHO \& SOARES, 2013, p. 19). 


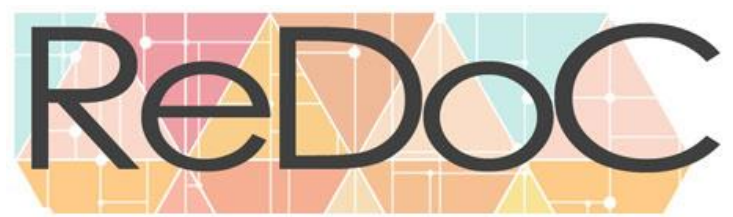

\section{Revista Docência e Cibercultura}

Na nossa contemporaneidade as juventudes são os maiores usuários nas/das redes sociais da internet, seja o Facebook, Twitter, Instagram, WhatsApp ou o YouTube. Estima-se que, pelo menos, nove em cada dez jovens possuam uma conta em uma rede social onde compartilham suas produções de fotos, vídeos, textos etc. em um processo de vigilância e visibilidade (BRUNO, 2013).

Trata-se do prazer e do poder de ver e ser visto, de mostrar e fazer ver, incitando e excitando a visão e o olhar, capturando, orientando e deslizando a atenção sobre a superfície de imagens. Se alguma verdade é buscada ali, ela se desloca do campo das causas recônditas para os efeitos visíveis. Os poderes, os saberes e os discursos que compõem o dispositivo da visibilidade engendram, sobretudo, efeitos de verdade e de realidade intimamente atrelados às imagens. As subjetividades, por sua vez, encontram-se cada vez mais exteriorizadas e investidas nos processos do ver e do ser visto, encontrando nas práticas de visibilidade meios de legitimação, reconhecimento e existência - as redes sociais, os reality shows, os fotologs, weblogs e webcams pessoais são ao mesmo tempo expressões e agentes desse processo. (BRUNO, 2010, p. 258. Grifo do autor).

Entendemos que os diferentes usos das redes sociais pelas juventudes possibilitam outros modos de produzir conhecimento e subjetividades atualmente.

Essas juventudes conectadas criam modismos, tendências, estilos musicais, canais, memes, tutoriais, promovendo outras formas de compreensão de si e do mundo e despertando, cada vez mais, interesse da mídia e de setores da sociedade em geral.

E são essas juventudes que estão presentes na nossa pesquisa, nos cotidianos das escolas com seus celulares e smartphones, clicando, compartilhando, curtindo, criando e cocriando novas maneiras de ser e novas formas de agir nos diversos espaçostempos que habitam na nossa "sociedade do compartilhamento" com o protagonismo das imagens.

$\mathrm{O}$ uso de imagens e as redes sociais da internet constituem uma das principais práticas das juventudes na nossa contemporaneidade. 


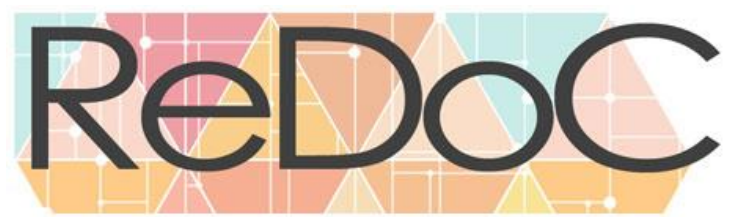

Revista Docência e Cibercultura

O mundo de imagens que é gerado, por sua vez, afeta a própria vida. Torna-se cada vez mais difícil fazer distinções entre vida, arte fantasia, realidade. Os campos confundem-se. A vida torna-se o modelo, a protoimagem do mundo de aparências e vice versa. O visual está em uma trajetória hipertrófica. (WULF, 2013, p.34).

Os regimes de verdade sobre o outro e sobre si estão cada vez mais produzidos e praticados com imagens que são curtidas e compartilhadas por essas juventudes.

\section{"COMPARTILHANDO": PENSANDO NA/DA DIFERENÇAS COM AS IMAGENS POSTADAS}

$\mathrm{Na}$ pesquisa tivemos um total de 45 imagens postadas e que serviram como discussão/debate entre os estudantes sobre diferença.

Algumas imagens postadas pelos estudantes da pesquisa, nos fazem pensar nas relações entre seres humanos que nos aproximamos de uma "diferença interpessoal".

Tratam-se de processos de singularização em que as pessoas vão se produzindo constantemente na relação com o mundo em seus processos de subjetivação, conforme os agenciamentos, as afetações, as configurações de forças e as experiências em suas múltiplas redes. Entendemos que as pessoas se constituem por assujeitamento ou em processos de subjetivação nos quais tomam as rédeas da invenção de suas próprias existências. Trata-se de exercer um poder sobre si próprio, de uma atitude problematizadora e performativa, interrogando-se como se tornou o que é/vai sendo e como é possível tornar-se outro numa perspectiva ética-estética-política que implicam escolhas, questionamento, tensão, enfrentamento, composição, criação permanente e potencialização dos modos de viver com outros.

Se pensarmos com Foucault (2013a), essa diferença processual, afirmativa e permanente impõe a tarefa de elaborar a si mesmo ou de inventar a si mesmo; um cuidado de si, que é indissociável de um cuidado com o outro. 


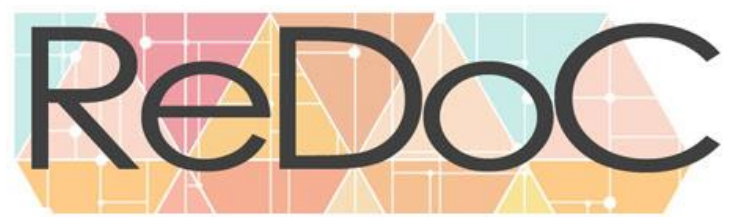

\section{Revista Docência e Cibercultura}

Assim, a imagem postada que vamos conversar neste texto, foi a imagem de uma carinha amarela sorrindo no meio de várias carinhas azuis tristes. Imagem essa, disponível em banco de dados da internet. Seguimos com os comentários dos estudantes:

A estudante D postou: "Para mim, a diferença é quando você deixa de ser ou seguir os outros para ser você mesmo, afinal, somos todos diferentes e, às vezes, as pessoas não entendem/aceitam isso. Porque você sendo você mesmo, não sendo igual aos outros, você aprende a se amar e a ser feliz."

O estudante E postou: "Achei interessante a imagem, primeira coisa que me veio à mente foi: se todos estão pensando a mesma coisa, ninguém está pensando. Aí, então, tem um ser pensante ali."

O estudante F postou: "Na minha opinião, a diferença somos nós que fazemos; no caso da imagem demonstra uma carinha feliz amarela e um grupo de carinhas tristes ao seu redor. Isso me fez lembrar uma forma de se vestir o preconceito, de se arrumar diferente, se você usa ou não usa roupa da moda, isso é uma grande diferença na sociedade e seu julgamento mesquinho."

Podemos pensar nos/com as imagens/comentários que os processos de singularização, tais como foi interpretada a "carinha amarela" da imagem postada, são considerados como prática de liberdade e se configuram como uma das alternativas de combate aos modelos de subordinação identitária ou de assujeitamento. Dessa forma, sai da relação de uma identidade hegemônica, do metro padrão. Contudo, a de lembrar-se com Foucault (2012b), que liberdade não é fazer o que se quer livremente, mas de não deixar que os outros (os poderes instituídos, as normas institucionais, as verdades científicas, midiáticas e religiosas etc.) façam tudo o que querem conosco. Mais ou menos como: o que podemos fazer com tudo aquilo que age no sentido de nos formatizar?

Fazer a diferença, entretanto, virou também uma palavra de ordem principalmente no mundo do trabalho e do consumo. Cabe então pensar a diferença processual, afirmativa, que potencializa e que é criadora de si, considerando que ela se efetua nesse mundo, com e apesar de tudo que nos é oferecido e/ou imposto. 


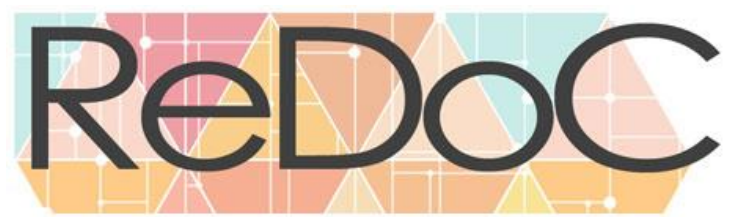

\section{Revista Docência e Cibercultura}

Embora possamos pensar em processos de invenção de si nos diálogos com as imagens por meio de problematizações feitas pelos/com os estudantes, muitos comentários nos remetem à ideia de tolerância, amor ao próximo, respeito, como atitudes necessárias e suficientes para combater a discriminação/marginalização/subalternização do que é apontado como diferente. Entendemos que embora essas atitudes sejam necessárias, não são suficientes para diminuir ou acabar com as desigualdades presentes.

Continuando nossa conversa com as contribuições de Michel Foucault (2013b) que, na sua trajetória e nos seus escritos, aponta relatos entre poder e a produção dos infames, dos diferentes, enfim, dos outros e aqui continua a nos ajudar a pensar a "diferença interpessoal".

O poder político, pelo menos em certas sociedades, em todo caso na nossa, pode se atribuir, e efetivamente se atribuiu, a possibilidade de transmitir seus efeitos, e muito mais que isso, de encontrar a origem dos seus efeitos num canto que é manifestamente, explicitamente, voluntariamente desqualificado pelo odioso, pelo infame ou pelo ridículo. Afinal de contas, essa mecânica grotesca de poder, ou essa engrenagem do grotesco na mecânica do poder, é antiquíssima nas estruturas, no funcionamento político das nossas sociedades. (FOUCAULT, 2013b, p. 11-12).

De acordo com o autor, saber e poder se coengendram.

Temos antes que admitir que o poder produz saber (e não simplesmente favorecendo-o porque o serve ou aplicando-o porque é útil); que poder e saber estão diretamente implicados; que não há relação de poder sem constituição correlata de um campo de saber, nem saber que não suponha e não constitua ao mesmo tempo relações de poder. Essas relações de "poder-saber" não devem então ser analisadas a partir do sujeito do conhecimento que seria ou não livre em relação ao sistema do poder; mas é preciso considerar ao contrário que o sujeito que conhece, os objetos a conhecer e as modalidades de conhecimento são outros tantos efeitos dessas implicações fundamentais do poder-saber e de suas transformações históricas. (FOUCAULT, 2012a, p. 30).

O poder se apresenta difuso e não apenas polarizado nas relações verticais, mas também nas relações sociais, nas instituições, nos grupos, exercendo assim um papel de 


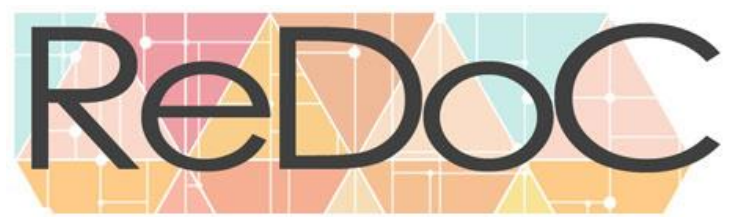

Revista Docência e Cibercultura

vigilantes e vigiados. Segundo Foucault (2012b), o poder não está somente no Estado: ele se encontra nas diversas relações humanas; ele também não é absoluto, pois onde encontramos relações de poder, podemos encontrar a resistência. O poder se exerce. É uma relação e, assim, está sempre sendo disputado; mais do que repressor, o poder é produtivo.

O que faz com que o poder se mantenha e que seja aceito é simplesmente que ele não pesa só como uma força que diz não, mas que de fato ele permeia, produz coisas, induz ao prazer, forma saber, produz discurso. Deve-se considerá-lo como uma rede produtiva que atravessa todo o corpo social muito mais do que uma instância negativa que tem por função reprimir. (FOUCAULT, 2012b, p. 45).

Importa-nos compreender como estes processos utilizados no século XVIII e XIX, na sua relação de produção do poder, podem ainda fazer parte da nossa sociedade contemporânea. Isso também não significa que sejamos iguais e que os mesmos mecanismos apontados e estudados por Foucault estejam sendo utilizados atualmente, mas demonstra como estes estudos, feitos na década de 70 do século XX, ainda refletem no século XXI.

Assim, em Microfísica do Poder, Foucault (2012b, p. 39) contribui para a compreensão da relação do poder e a ciência:

[...] Neste nível não se trata de saber qual é o poder que age do exterior sobre a ciência, mas que efeitos de poder circulam entre os enunciados científicos; qual é o seu regime interior de poder; como e por que em certos momentos ele se modifica de forma global.

Foucault (2013a) também nos mostra os conceitos de qualificação e desqualificação que se encontram engendrados nos discursos, dando uma maior ou menor visibilidade a grupos, pessoas, classes que não compartilham do poder, conduzindo-os a uma condição de subalternidade.

[...] Ubu é o exercício do poder através da desqualificação explicita de quem o exerce, se o grotesco político é a anulação do detentor do poder pelo próprio ritual que manifesta esse poder e esse detentor, vocês hão de convir que o perito psiquiatra na verdade não pode deixar de ser a própria personagem Ubu. Ele pode exercer o terrível poder que lhe pedem para exercer - e que, no fim das contas, é o de determinar a punição de um indivíduo ou dela participar em boa parte - por meio de 


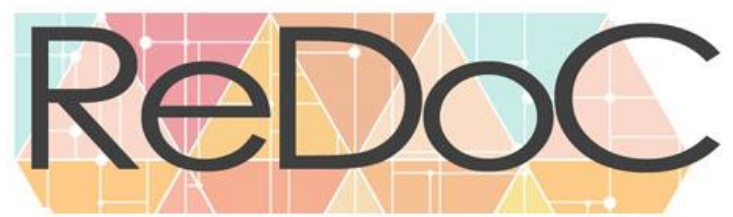

Revista Docência e Cibercultura

um discurso infantil, que o desqualifica como cientista quando foi precisamente pelo título de cientista que o convocaram, e por meio de um discurso de medo, que o ridiculariza precisamente quando ele fala num tribunal a propósito de alguém que está no banco dos réus e que, por conseguinte, está despojado de todo e qualquer poder. Ele fala a linguagem da criança, fala da linguagem do medo, logo ele, que é o cientista, que está ao abrigo, protegido, sacralizado até, por toda a instituição judiciária e sua espada. Essa linguagem balbuciante, que é a do exame, funciona precisamente como aquilo que vai transmitir, da instituição judiciária à instituição médica, os efeitos do poder que são próprios a uma e a outra, através da desqualificação daquele que faz junção [...]. (FOUCAUT, 2013a, p. 31).

Podemos observar nesses estudos, que as pessoas que não estavam enquadradas na relação da normalidade, eram afastadas; as que não eram "normais", eram afastadas do convívio social, eram assim marginalizadas. Muitas pessoas ainda continuam passando por esse processo de segregação e marginalização.

Dessa maneira, a desqualificação é utilizada como um importante elemento no que Foucault (2013a) aponta como "poder de normalização", impondo àquele classificado como anormal, a sua exclusão do convívio social.

[...] Ora, é sob essa forma que se descreve, e a meu ver ainda hoje, a maneira como o poder se exerce sobre os loucos, sobre os doentes, sobre os criminosos, sobre os desviantes, sobre as crianças, sobre os pobres. Descrevem-se em geral os efeitos e os mecanismos de poder que se exercem sobre eles como mecanismos e efeitos de exclusão, de desqualificação, de exílio, de rejeição, de privação, de recusa, de desconhecimento, ou seja, todo o arsenal dos conceitos e mecanismos negativos da exclusão. [...] (FOUCAUT, 2013a,p. 37-38)

É importante salientar que, na concepção foucaultiana, o poder não tem exclusivamente uma conotação negativa de repressão e dominação; o poder faz parte da sociedade e dos indivíduos que a compõem. O poder é produtivo e produz subjetividades.

Podemos observar nas marcas deixadas pelo pensamento Moderno e enunciadas por Foucault em suas obras, que a disciplina e a norma produziram novas tecnologias de governabilidade, principalmente, no que se refere ao tempo e ao espaço, com as 


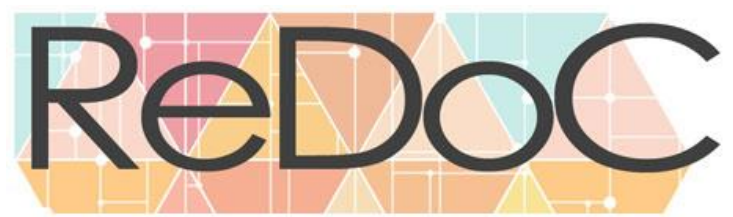

\title{
Revista Docência e Cibercultura
}

instituições que assumiram o papel de identificar e principalmente segregar aqueles que foram considerados desviantes dentro das clínicas, prisões ou internatos.

Foucault (2012a) demonstra que a prisão, o hospital, a fábrica, o quartel, o manicômio, a escola, considerados espaços de disciplinarização, por exemplo, não se encontram somente como um espaço de punição, mas espaços de moldagem, de adestramento para reeducar, corrigir e, de certa forma, controlar os corpos, produzindo “corpos dóceis e produtivos" e subjetividades subalternas, garantindo desta forma, as relações sociais de dominação.

\begin{abstract}
Esquemas diferentes, portanto, mas não incompatíveis. Lentamente, vemo-los se aproximarem; e é próprio do século XIX ter aplicado ao espaço de exclusão de que o leproso era o habitante simbólico (e os mendigos, os vagabundos, os loucos, os violentos formavam a população real) a técnica de poder própria do "quadriculamento" disciplinar. Tratar os "leprosos" como pestilentos, projetar recortes finos da disciplina sobre o espaço confuso do internamento, trabalhá-lo com os métodos de repartição analítica do poder, individualizar os excluídos, mas utilizar processos de individualização para marcar exclusões - isso é o que foi regularmente realizado pelo poder disciplinar desde o começo do século XIX: o asilo psiquiátrico, a penitenciária, a casa de correção, o estabelecimento de educação vigiada, e por um lado os hospitais, de um modo geral todas as instâncias de controle individual funcional num duplo modo: o da divisão binária e da marcação (louco-não louco; perigoso-inofensivo; normal-anormal);e o da determinação coercitiva, da repartição diferencial (quem é ele, onde deve estar, como caracterizá-lo, como reconhecê-lo; como exercer sobre ele, de maneira individual, uma vigilância constante etc.) (FOUCAULT, 2012a, p. 189).
\end{abstract}

Neste momento, a classificação tem um grande destaque num processo que se inicia com a identificação para que haja diagnóstico; do diagnóstico para que haja classificação; da classificação para que haja segregação e da segregação para que haja a exclusão ou cura em uma inclusão perversa do outro "reformado".

Dessa forma, uma gama de especialistas acaba tendo destaque nesse processo de exclusão em que os ditos "normais" poderiam viver em sociedade e os "desviantes" teriam que permanecer segregados no isolamento. A disciplina, assim, se coloca como 


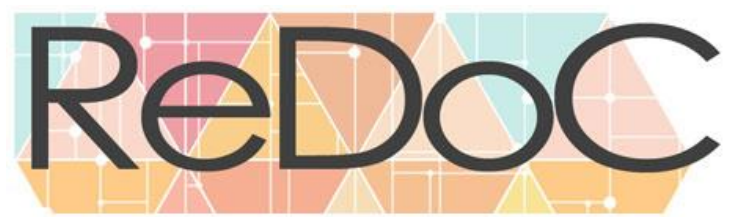

\section{Revista Docência e Cibercultura}

grande aliada para que, nessa visão, possa ser aplicada a esses processos de exclusão das pessoas, dos desviantes, dos anormais na sociedade hierarquizada.

A disciplina "fabrica" indivíduos; ela é a técnica específica de um poder que toma os indivíduos ao mesmo tempo como objetos e como instrumentos de seu exercício. Não é um poder triunfante que, a partir de seu próprio excesso, pode-se fiar em seu super poderio; é um poder modesto, desconfiado, que funciona a modo de uma economia calculada, mas permanente. (FOUCAULT, 2012a, p. 164).

Se no passado, a classificação excluía alguns desviantes ou anormais, hoje podemos dialogar que esse processo se faz e se dá com todos esses "diferentes" apontados pelos estudantes.

Observamos que as relações de poder e saber ainda classificam os indivíduos nos diversos espaçostempos da nossa sociedade, engendrando forças de exclusão ou inclusão, sejam nas escolas, nas empresas, nas famílias.

\section{“COMENTANDO": URDINDO PONTOS DA PESQUISA}

Destarte, estamos imersos em uma cultura visual e digital, na chamada Era da Tecnologia e da Informação numa sociedade permeada por diversas redes sociais da/na internet, tais como Facebook, Twitter, Instagran etc., que aqui denominamos o conceito de "sociedade do compartilhamento", pois entendemos que, nessas contingências, praticar textos e imagens, conhecimentos e processos de significação, implica, cada vez mais, em compartilhar o que é visto, produzido, postado, armazenado e comentado.

Assim, na "sociedade do compartilhamento", as redes sociais da internet vêm ocupando um papel protagonista nas relações que são urdidas na nossa contemporaneidade; imagens, pensamentos e opiniões, as mais diversas existentes, são publicadas, curtidas, comentadas e compartilhadas.

Compartilhar material significante (FRANÇA, 2006), deslocando, transportando, desterritorializando, reterritorializando e refuncionalizando colaborativamente tornou-se 


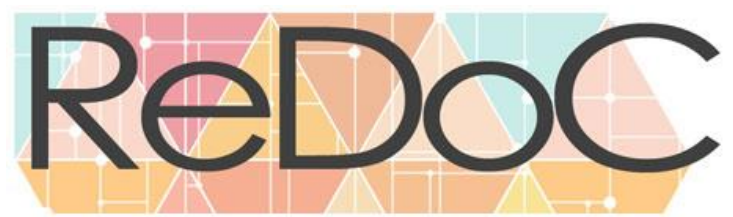

\section{Revista Docência e Cibercultura}

uma forma de se apropriar e de ressignificar imagens, palavras, frases e ideias, forjadas ou, ao menos, intensificadas com as novas mídias. Instituíram-se, assim, com o digital em redes, novos/outros modos de pensar e expressar, de tecer ideias/conceitos com os outros: outras pessoas, textos, imagens, ideias, que estão disponíveis e acessíveis na/com a internet e que se oferecem ou se impõem a nós, seja quando navegamos despretensiosamente para divertir-nos, seja quando realizamos pesquisas em sites de busca. São materiais significantes, produzidos em outros sistemas de produção e usos que, quando desterritorializados, flutuando nas "nuvens" ou em inúmeros espaçostempos das redes digitais, podem ser reterritorializados com os usos que fazemos deles, passado de um sistema de usos a outros.

Defendemos que essa discussão produziu questões, provocou estranhezas e abalou certezas, abrindo espaço para a dúvida a fim de que cada um pudesse reorganizar-se. Nos encontros com os estudantes em pesquisa, acreditamos que se forjaram processos de subjetivação e novas possibilidades para a ação e a conexão com o mundo e o outro.

Nesse sentido, entendemos que as perspectivas curriculares nos diversos processos que se constituem, as imagens estão cada vez mais presentes e incorporadas nos múltiplos contextos de aprendizagem.

Engendradas a esses processos e contextos curriculares, entendemos que as questões ligadas à diferença, que se cruzem e entrecruzam num diálogo potente no cotidiano das escolas, extraindo a diferença engessada como algo negativo da identidade, corroborem para a multiplicidade dos processos curriculares.

E assim seguiremos clicando, postando, compartilhando, curtindo e comentando. 


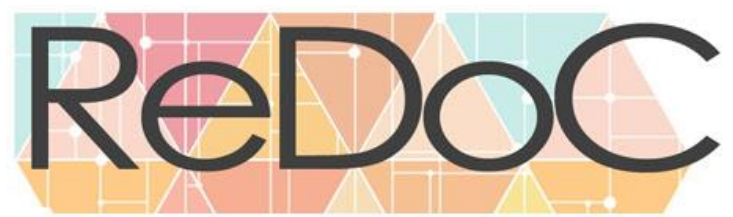

Revista Docência e Cibercultura

\section{REFERÊNCIAS}

ALVES, Nilda. Decifrando o pergaminho: os cotidianos das escolas nas lógicas das redes cotidianas. In: ALVES, Nilda; OLIVEIRA, Inês B. de (Orgs.). Pesquisa nos/dos/com os cotidianos das escolas. 3. ed. Petrópolis, RJ: DP, 2008, p. 15-38.

A formação com imagens. In: Revista Interinstitucional Artes de Educar, Rio de Janeiro, 2 v., n. Especial, p. 235-52, jun./out., 2016.

AMANTE, Lúcia. Facebook e novas sociabilidades: contributos da investigação. In: PORTO, Cristiane; SANTOS, Edméa (Orgs.). Facebook e Educação: publicar, curtir, compartilhar. Campina Grande: EDUEPB, 2014, p. 27-46.

BERINO, Aristóteles; VICTÓRIO FILHO, Aldo; SOARES, Maria da Conceição Silva. Uma introdução: por dentro e por fora das juventudes. In: BERINO, Aristóteles; VICTÓRIO FILHO, Aldo; SOARES, Maria da Conceição Silva (Orgs.). A fartura das juventudes: tramas entre educação, mídia e arte. Rio de Janeiro: Nau, 2013.

BHABHA, Homi. O local da cultura. Belo Horizonte: UFMG, 2001.

BRUNO, Fernanda. Circuitos de vigilância: controle, libido e estética. In: LEAL, Bruno Souza; MENDONÇA, Carlos Camargos; GUIMARÃES, César. Entre o sensível e o comunicacional. Belo Horizonte: Autêntica, 2010, p. 253-76.

Fernanda, Máquinas de ver, modos de ser: vigilância, tecnologia e subjetividade. Porto Alegre: Sulina, 2013.

CERTEAU, Michel de; GIARD, Luce. Entremeio. In: CERTEAU, Michel de; GIARD, Luce; MAYOL, Pierre. A invenção do cotidiano: 2. morar, cozinhar. Petrópolis, RJ: Vozes, 1996,

DELEUZE, Gilles. Diferença e Repetição. Portugal: Ed. Relógio D’Água, 2000.

FLUSSER, Vilém. Filosofia da Caixa Preta. São Paulo: ANNABLUME, 2011.

FOUCAULT, Michel. Em defesa da sociedade. 2. ed. São Paulo: Martins Fontes, 2010. . Vigiar e Punir. 40. ed. Petrópolis, RJ: Vozes, 2012a.

. Microfísica do Poder. 25. ed. São Paulo: Graal, 2012b. 


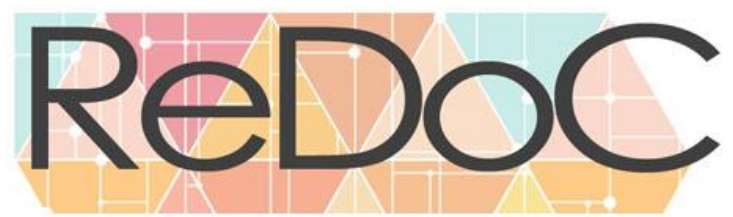

Revista Docência e Cibercultura

. Os Anormais. 2. ed. São Paulo: Martins Fontes, 2013a.

. Ditos e Escritos II: arqueologia das ciências e história dos Sistemas de

Pensamento. 3. ed. Rio de Janeiro: Forense, 2013b.

FRANÇA, Vera. Sujeito da comunicação: sujeitos em comunicação. In: GUIMARÃES, César; FRANÇA, Vera (Orgs.). Na mídia, na rua: narrativas do cotidiano. Belo Horizonte: Autêntica, 2006.

KASTRUP, Virgínia. A invenção de si e do mundo: uma introdução do tempo e do coletivo no estudo da cognição. Belo Horizonte: Autêntica, 2007.

MACHADO, Arlindo. O quarto iconoclasmo e outros ensaios hereges. Rio de Janeiro: Marca D’Água, 2001.

MÉDOLA, Ana Sílvia; ARAUJO, Denize; BRUNO, Fernanda (Orgs.). Imagem Visibilidade e Cultura Midiática. Porto Alegre: Sulina, 2007

MOREIRA, José Antônio; JANUÁRIO, Susana. Redes sociais e educação: reflexão acerca do Facebook enquanto espaço de aprendizagem. In: PORTO, Cristiane; SANTOS, Edméa (Orgs.). Facebook e Educação: publicar, curtir, compartilhar. Campina Grande, PB: EDUEPB, 2014, p. 67-84.

SANTOS, Edméa. Pesquisa Formação na Cibercultura. Portugal: Whitebooks, 2014.

SOARES, Conceição; SANTOS, Edméa. Artefatos tecnoculturais nos processos pedagógicos: usos e implicações para os currículos. In: ALVES, Nilda; LIBÂNEO, José Carlos (Orgs.). Temas de Pedagogia diálogos entre didática e currículo. São Paulo: Cortez, 2012, p. 308-32.

WULF, Christoph. Homo Pictor: imaginação, ritual e aprendizado mimético no mundo globalizado. São Paulo: Hedra, 2013. 